\title{
Evaluation of deformation and fracture rates for nickel-titanium rotary instruments according to the frequency of clinical use
}

\section{Purpose}

To evaluate the deformation and fracture rates for ProTaper Universal (PTU) nickeltitanium rotary instruments according to the frequency of clinical use.

\section{Materials and Methods}

A total of 619 PTU instruments (S1, S2, F1, F2, and F3) that have been used in the clinic by a single endodontist were collected over a period of 4 years. These instruments were grouped on the basis of one to three (Group A), four to six (Group B) and seven to nine (Group C) clinical uses (one canal = one use). All instruments were evaluated by a blinded investigator under a stereomicroscope at $15 x-45 x$ magnification for the presence of deformation and fracture.

\section{Results}

The overall rates of deformation and fracture were $10 \%$ and $1.2 \%$, respectively. The deformation and fracture rates for the S2, F1, and F2 instruments showed no significant differences among groups. However, fracture rate for S1 instruments in Group A was significantly higher than for those in Group B $(p=0.025)$ and Group C $(p=0.004)$. In Group $C$, the $S 1$ instruments showed a significantly higher deformation rate compared with the $S 2(p=0.04), F 1(p=0.008)$ and F2 ( $p=0.049)$ instruments; there were no other significant differences within groups.

\section{Conclusion}

Under the conditions of the current study, frequency of use seemed to influence the deformation rates of PTU rotary instruments. Except S1, these instruments could be used without any fracture or deformation in up to 9 clinical cases by an experienced endodontist.

Keywords: NiTi rotary system; ProTaper Universal; dental instruments; deformation; fracture

\section{Introduction}

Nickel-titanium (NiTi) rotary instruments have gained increasing popularity since their first introduction and are now widely used in endodontic practice. Currently, a variety of NiTi rotary systems marketed by various manufacturers are available. However, despite improvements in their cutting efficiency and flexibility, the possibility of unexpected separation during use remains a major concern $(1,2)$. Separation can be caused by torsional failure or flexural fatigue (3); the former is generally accompanied by macroscopic distortion or unwinding of the flutes, whereas the latter often presents unexpectedly with no unwinding defects (4).

It is widely accepted that NiTi rotary instruments fail with incorrect or excessive use (5). Furthermore, there is a perception among clinicians and researchers that the frequency of use may be an important factor affecting instrument failure (6). Most manufacturers advocate that their NiTi rotary files should be used only once to minimize the frequency of fracture. Others recommend that the instrument should be regularly discarded after a certain number of uses, generally one to 10 , to prevent fracture (7-11).

\author{
Ayça Yılmaz', \\ Sıtkı Selçuk Gökyay ${ }^{1}$, \\ Rüştü Dağlaroğlu' ${ }^{1}$, (i) \\ Işıl Karagöz Küçükay² (])
}

ORCID IDs of the authors: A.Y. 0000-0002-9254-7710; S.S.G. 0000-0003-2660-6329; R.D. 0000-0003-1438-5530; I.K.K. $0000-0002-4957-7850$

${ }^{1}$ Department of Endodontics, istanbul University Faculty of Dentistry, Istanbul, Turkey

${ }^{2}$ Department of Endodontics, Okan University Faculty of Dentistry, Istanbul, Turkey

Research poster presentation, European Society of Endodontology $15^{\text {th }}$ Biennial Congress, Rome Cavalieri Hotel, Rome, Italy, 15-17 September 2011.

Corresponding Author: Ayça Yılmaz E-mail: ayca.yilmaz@istanbul.edu.tr

Received: 25 April 2017 Revised: 17 May 2017 Accepted: 13 July 2017 DOI: 10.26650/eor.2018.461 
However, there is no consensus regarding the optimal number of uses.

The ProTaper Universal (Dentsply Maillefer, Ballaigues, Switzerland) system is originally comprised six instruments, including three shaping files (SX-optional, S1, and S2) and three finishing files (F1, F2, and F3). Subsequently, F4 and F5 finishing files for wider canals were introduced. These files have a convex triangular cross-sectional shape with sharp cutting edges and no radial lands. A unique design element is the presence of varying tapers over the length of the shaft of each instrument. The taper of the three shaping files increases coronally, while that of the finishing files increases apically (12).

The aim of this retrospective study was to evaluate the deformation and fracture rates for ProTaper Universal NiTi rotary instruments with regard to the frequency of clinical use.

\section{Materials and methods}

A total of 619 ProTaper Universal NiTi rotary instruments (S1, S2, F1, F2, and F3) were included in this retrospective study. These instruments were collected after clinical use by a single endodontist at the Department of Endodontics, Faculty of Dentistry, İstanbul University over a period of 4 years (2007-2010). The risk of instrument fracture during treatment was explained to all patients, and written informed consent was obtained from each patient as a routine clinical procedure.

\section{Instrumentation technique}

After appropriate access cavity preparation, root canals were cleaned and shaped using the ProTaper Universal rotary instruments attached to an air-driven Endo NiTi WD 73M handpiece (W\&H Dentalwerk, Bürmoos, Austria) at 150-200 rpm by an endodontist with nearly seven years of experience with this system. The operative sequence is described below.

i. Number 10 and $15 \mathrm{~K}$-type hand files (Dentsply Maillefer) were pre-curved and passively inserted into the coronal two-thirds of the root canal as pathfinding files.

i. The coronal two-thirds were prepared using ProTaper Universal S1 and S2 files with a brushing motion.

ii. Hand files were then used to secure a glide path and determine the working length with an electronic apex locator and/or radiograph.

iii. S1 and S2 files were used up to the full working length.

iv. The preparation was finished with F1, F2 or F3 files according to the complexity of the root canal anatomy. The finishing files were used with a non-brushing motion (12).

v. During preparation, only light apical pressure was applied to the rotary instruments.

vi. Glyde File Prep (Dentsply Maillefer) was used as a lubricant, and $2 \mathrm{ml}$ of $2.5 \%$ sodium hypochlorite solution was used for irrigation after the use of each file.

All instruments were autoclaved under standardized conditions before use. Following instrumentation, they were ultrasonically cleaned and autoclaved under standardized conditions.

\section{Collection of discarded instruments}

After each use, the instruments were wiped with a piece of gauze soaked with isopropyl alcohol and examined with the naked eye for the presence of any defects. The instrument was discarded when it showed deformation and was classified into one of the groups based on the frequency of clinical use. In severely curved or calcified canals, a new set of ProTaper Universal rotary instruments was used and discarded even if they showed no deformation. The decision regarding the frequency of use was at the discretion of the endodontist. Other routinely used instruments were randomly discarded without any signs of deformation under the naked eye and grouped accordingly.

All collected instruments were classified into three groups on the basis of one to three (Group $A ; n=113$ ), four to six (Group B; $n=168$ ) and seven to nine (Group $C ; n=338$ ) clinical uses. Instrumentation of a single canal represented one clinical use. Accordingly, instrumentation of one tooth with three canals represented three clinical uses.

\section{Examination of discarded instruments}

All groups of instruments were evaluated for the presence of deformation and fracture under a stereomicroscope (Leica MZ75, Leica Imaging Systems Ltd, Cambridge, UK) at 15×-45× magnifications by another experienced pre-calibrated endodontist who was blinded to the number of clinical uses. All defects such as unwinding, curving or bending were simply defined as deformation, regardless of the magnitude (Figure 1).

During the stereomicroscopic evaluation, a new, unused, sterilized ProTaper Universal rotary instrument of the same type was placed beside the used instrument for easy and accurate assessment of deformation or fracture in the same screen (Figures 2, 3).

\section{Statistical analysis}

The data were analyzed using NCSS 2007 Statistical Software (NCSS, LLC, Kaysville, Utah, USA). Frequency values were used for the descriptive statistics. All data were statistically analyzed using Fisher's exact test. A p-value of $<0.05$ was considered statistically significant.

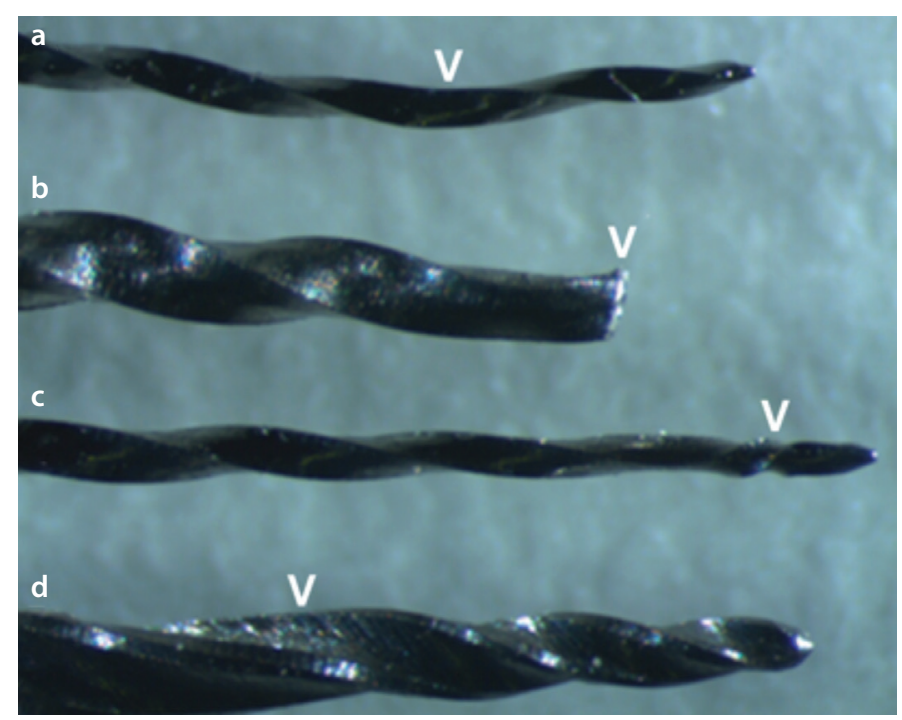

Figure 1. a-d. Stereomicroscopic images of ProTaper Universal instruments. Deformation $(a, c, d)$ and fracture (b) can be observed (arrowheads) under $24 \times$ magnification. 

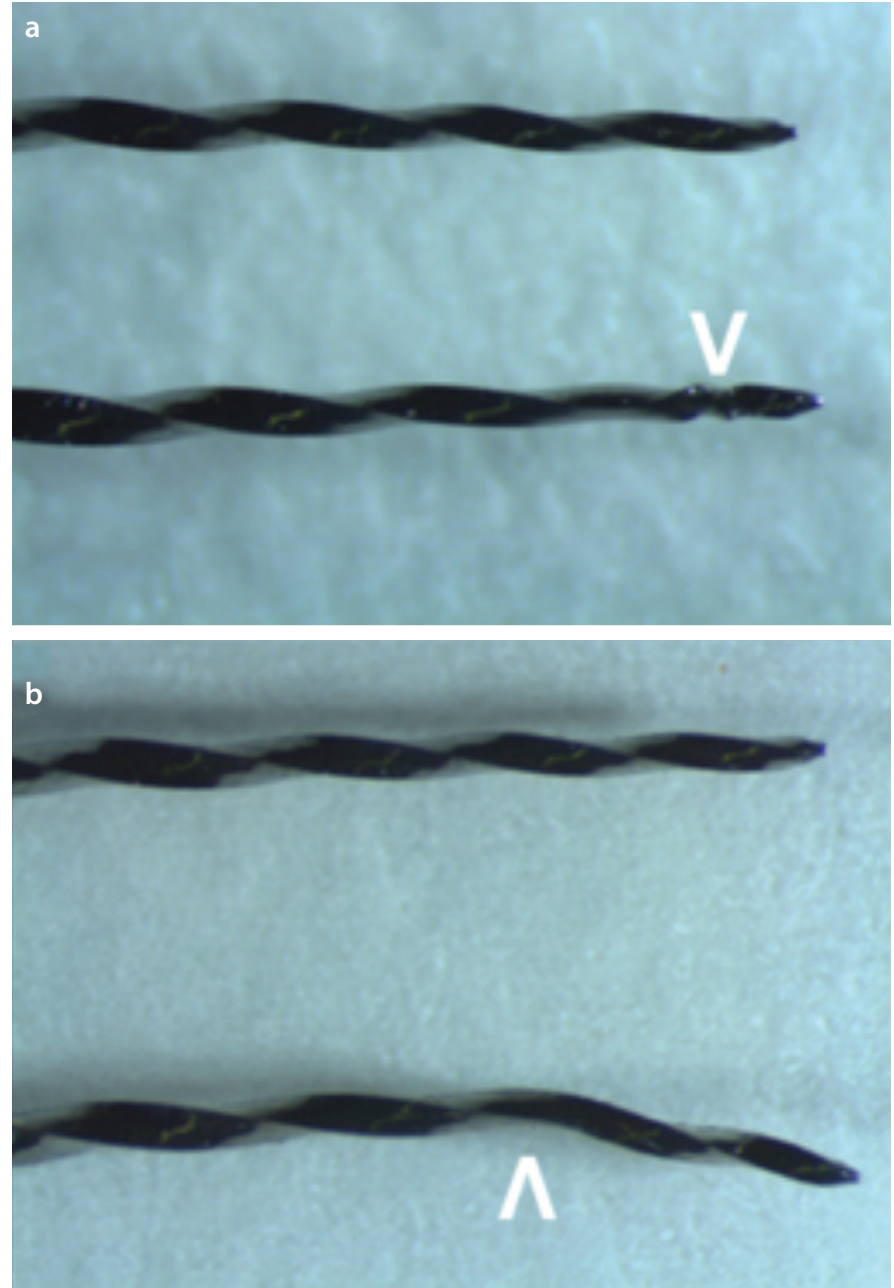

Figure 2. $\boldsymbol{a}, \boldsymbol{b}$. Stereomicroscopic images of unused and used, sterilized ProTaper $\mathrm{S} 1$ instruments. Deformations can be observed (arrowheads) under $24 \times$ magnification.
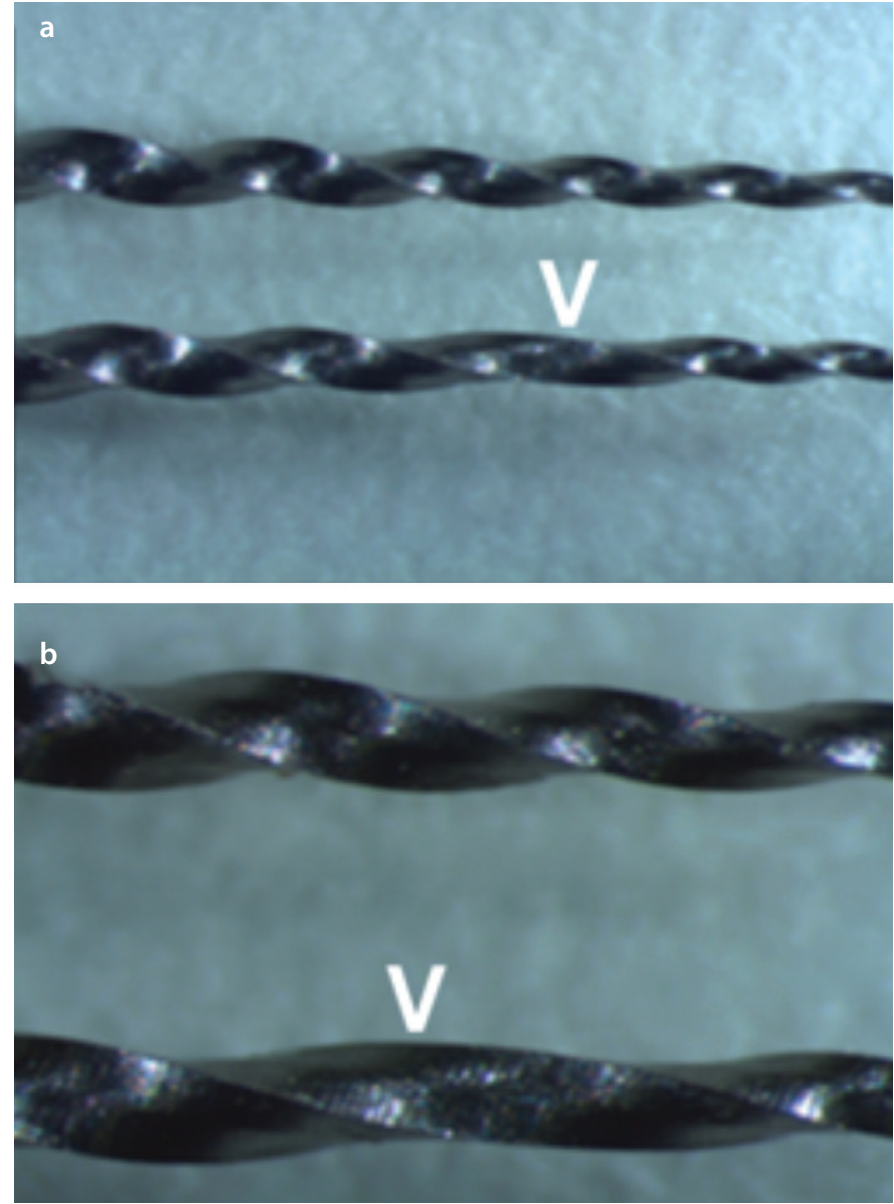

Figure 3. $\boldsymbol{a}, \boldsymbol{b}$. Stereomicroscopic images of an unused and a used, sterilized ProTaper F1 instruments. (a) Slight deformation (arrowhead) of the used instrument is noted under $15 \times$ magnification, (b) Image of the same instrument under $30 \times$ magnification reveals considerable deformation (arrowhead).

\begin{tabular}{|c|c|c|c|c|c|c|}
\hline Groups & & S1 n (\%) & S2 n (\%) & F1 n (\%) & F2 n (\%) & F3 n (\%) \\
\hline \multirow[t]{3}{*}{ Group A } & No defect & 26 (76.47) & $29(100)$ & 25 (89.29) & $14(100)$ & 7 (87.5) \\
\hline & Deformation & $4(11.76)$ & $0(0.00)$ & $2(7.14)$ & $0(0.00)$ & $1(12.50)$ \\
\hline & Fracture & $4(11.76)$ & $0(0.00)$ & $1(3.57)$ & $0(0.00)$ & $0(0.00)$ \\
\hline \multirow[t]{3}{*}{ Group B } & No defect & $43(87.76)$ & $44(89.80)$ & $51(94.44)$ & 15 (93.75) & $0(0.00)$ \\
\hline & Deformation & $6(12.24)$ & $5(10.20)$ & $2(3.70)$ & $1(6.25)$ & $0(0.00)$ \\
\hline & Fracture & $0(0.00)$ & $0(0.00)$ & $1(1.85)$ & $0(0.00)$ & $0(0.00)$ \\
\hline \multirow[t]{3}{*}{ Group C } & No defect & 79 (79.00) & $88(88.89)$ & 99 (92.52) & $29(90.63)$ & $0(0.00)$ \\
\hline & Deformation & $21(21.00)$ & $10(10.10)$ & $8(7.48)$ & $2(6.25)$ & $0(0.00)$ \\
\hline & Fracture & $0(0.00)$ & $1(1.01)$ & $0(0.00)$ & $1(3.13)$ & $0(0.00)$ \\
\hline
\end{tabular}

Group A: 1-3 clinical uses ( $n=113)$, Group B: 4-6 clinical uses $(n=168)$, Group C: $7-9$ clinical uses $(n=338)$

\section{Results}

The overall rate of instrument deformation was $10 \%$, while that of instrument fracture was $1.2 \%$ (Table 1).

The S2, F1, and F2 instruments showed no statistically significant differences with regard to the deformation and fracture rates among the three groups $(p>0.05)$. However, the $\mathrm{S} 1$ instruments showed a significantly higher incidence of fracture when used one to three times than when used four to six $(p=0.025)$ and seven to nine $(p=0.004)$ times; the deformation rate was not significantly different $(p>0.05)$.

When instruments were compared within each group, the $\mathrm{S} 1$ instruments showed a higher rate of deformation compared with the S2 $(p=0.04), F 1 \quad(p=0.008)$ and F2 $(p=0.049)$ instruments when used seven to nine times. No other significant differences were noted.

Because larger and stiffer ProTaper Universal instruments were reported to be reused with caution $(4,9)$, to use F3 in- 
struments more than three times was not preferred, and therefore, these instruments were not included in the statistical analyses.

\section{Discussion}

The aim of this retrospective study was to evaluate the deformation and fracture rates for ProTaper Universal NiTi rotary instruments with regard to the frequency of clinical use. The frequency of use of NiTi rotary instruments depends on the complexity of the root canal anatomy and structure (4). One of the main causes of instrument fracture is a severely curved root canal $(13,14)$. However, one study has reported that there is no correlation between the frequency of use and the fracture rate (15). In the present study, the overall rate of instrument fracture was 1.2\%, and S1 instruments showed a higher incidence of fracture when used one to three times than when used four to six $(p=0.025)$ and seven to nine $(p=0.004)$ times. The protocol for challenging cases is to use a new set of ProTaper Universal rotary instruments and discard these instruments after a single clinical use; possible deformation of only S1 instruments from the set after single use in challenging cases seems to be a plausible explanation for the statistical results obtained in the current study.

The overall rate of instrument deformation was $10 \%$ in the present study, with no significant differences among any instrument types in each group except Group C (seven to nine uses), where S1 showed the highest incidence. Shen et al. (4) reported a $0 \%$ failure rate for all ProTaper Universal files except S1 files, and their findings corroborated with those in studies showing a high incidence of distortion and separation with smaller NiTi instruments $(11,15)$. Ullmann and Peters (16) also found that SX and S2 files were more resistant to torque than S1 files. These findings support those of the present study, where a higher deformation rate was found for $\mathrm{S} 1$ than for S2 $(p=0.04), F 1(p=0.008)$ and F2 $(p=0.049)$ with seven to nine uses. This was possible because S1 has the smallest diameter among the ProTaper files and is the first rotary instrument used in canals as per the routine protocol (12).

The fracture rate is reported to vary according to the evaluation method (17). Wolcott et al. (9) reported a $2.4 \%$ rate of instrument fracture after the treatment of five teeth, including retreated teeth. In contrast, Wei et al. (18) found a $12 \%$ incidence of instrument separation after the treatment of 30 canals. In addition, Vieira et al. (6) mentioned that the use of ProTaper rotary instruments by an experienced endodontist allowed for the cleaning and shaping of up to 24-32 root canals without fracture. In their study, operator experience was found to affect the incidence of fracture and plastic deformation of files during shaping (6). In the present study, the fracture rate was $1.2 \%$, which was lower than that in the abovementioned studies. Taken together, these findings indicate that the endodontist who performed all procedures in our study performed the treatment meticulously.

The deformation rate has also been reported to vary from $2.9 \%$ (19) to $12 \%$ (15) with different evaluation methods. In the present study, the deformation rate was higher than that in a study by Shen et al. (19), who evaluated instruments used only once. On the other hand, our findings were similar to those of Parashos et al. (15), who evaluated instruments used multiple times.

Wu et al. (17) mentioned that the fracture rate of reused ProTaper Universal rotary instruments remains low in endodon- tic practice, where the separation rate based on the number of treated canals is more reliable than that based on the number of treated teeth. In the present study, assessments were made on the basis of the number of treated canals.

Gambarini (20) reported that torque-controlled motors, which have been used for several years, increase operational safety. However, some authors reported that torque-controlled motors might be primarily useful for inexperienced clinicians (21), whereas others have found no significant difference in the instrument fracture rate between air-driven and electrical handpieces (22). In the present study, ProTaper Universal instruments were used with an air-driven W\&H Endo NiTi handpiece according to the preference of the endodontist.

To avoid the risk of cross-contamination with the increased frequency of use, we sterilized each instrument before each use, which is mandatory. Some authors (23) have pointed out the negative effects of sterilization on the instrument durability, although others have reported contradictory results (24). In future studies, the sterilization process of the files may be undertaken after each use in a canal rather than a tooth to standardize the number of sterilizations and avoid the possible variable effects on the instrument durability.

Several recommendations have been proposed to prevent NiTi rotary instrument fracture, such as following a specific instrumentation protocol, shaping coronal third before the negotiation of the root canals, avoiding application of excessive apical pressure on the rotary instruments, preventing the rotation of the file at a single spot and the use of lubricants. In previous studies on the defect rates for clinically used NiTi rotary instruments, the most important factor was reported to be the skill of the operator (25-27). Parashos et al. (15) also concluded the same, and associated the defect rate with clinical skills or a conscious decision to use the instruments for a specified number of times or until the defects were evident. There is no agreement in the literature with regard to an association between the frequency of use and instrument fracture. Many authors have accepted that the failure of NiTi rotary files is influenced more by the manner of use than by the frequency of use (19). Although all clinical procedures were performed by an experienced endodontist and all recommendations and criteria were fulfilled with great care, the lack of comparisons with results obtained by an inexperienced user was a limitation of the present study.

\section{Conclusion}

ProTaper Universal has been one of the most extensively studied NiTi rotary instrument systems in the field of endodontics. However, the deformation and fracture rate results remain equivocal because of the presence of several influencing factors such as sterilization, handpiece use instead of torque-controlled motors, root canal anatomy, operator skill, and frequency of use. Under the conditions of the current study, frequency of use seemed to influence the deformation rates of PTU rotary instruments. Except S1, these instruments could be used without any fracture or deformation in up to 9 clinical cases by an experienced endodontist.

\section{Ethics Committee Approval: Not required.}

Informed Consent: Written informed consent was obtained from all patients involved in this study. 
Peer-review: Externally peer-reviewed.

Author Contributions: AY and IKK designed the study. AY, SSG, RD and IKK generated the data. AY, SSG and IKK gathered and analyzed the data, wrote the majority of the original draft. All authors approved the final version of the paper.

Acknowledgements: We thank Assoc. Prof. Dr. Alp Saruhanoğlu for his comments that greatly improved the manuscript.

Conflict of Interest: The authors have no conflicts of interest to declare.

Financial Disclosure: The authors declared that this study has received no financial support.

Türkçe öz: Nikel-titanyum döner aletlerin klinik kullanım sıklığına göre kırılma ve deformasyon oranlarının değerlendirilmesi. Amaç: Bu çalışmanın amacı, ProTaper Universal (PTU) nikel-titanyum döner aletlerinin deformasyon ve kırılma oranlarının klinik kullanım sıklığına göre değerlendirilmesidir. Gereç ve Yöntem: Çalışmada 4 yıl boyunca, bir endodontistin klinik kullanımı sonrası toplanan 619 PTU (S1, S2, F1, F2 ve F3) alet değerlendirilmiştir. Bu aletler; 1-3 (A grubu), 4-6 ( $B$ grubu) ve 7-9 (C grubu) klinik kullanım miktarı olacak şekilde 3 gruba ayrılmıştır (1 kanal=1 kullanım). Kullanılan aletler deformasyon ve kırık varlığı açısından kullanım sayısını bilmeyen bir araştırıcı tarafından stereo mikroskop ile 15x-45x büyütmede değerlendirilmiştir. Bulgular: Bütün grupların oranları birlikte değerlendirildiğinde, deformasyon yüzdesi \%10 ve kırık yüzdesi \%1,2'dir. Deformasyon ve kırılma yüzdeleri oranları açısından S2, F1 ve F2 aletleri arasında istatistiksel olarak anlamlı bir fark saptanmamıştır. A grubundaki S1 aletlerinin kırılma oranı, $B(p=0,025)$ ve $C$ gruplarındakilere $(p=0,004)$ kıyasla daha yüksek bulunmuştur. $C$ grubunda, S1 aleti, S2 $(p=0,04), F 1(p=0,008)$ ve F2 $(p=0,049)$ aletlerine kıyasla istatistiksel olarak anlamlı derecede yüksek deformasyon oranı göstermiştir; B ve C gruplarında ise anlamlı bir fark saptanmamıştır. Sonuç: Bu çalışmanın şartları altında, PTU aletlerinin deformasyon ve kırık oranları kullanım sıklığına göre değişiklik göstermektedir. Tecrübeli bir endodontist tarafından klinik uygulamada S1 haricindeki aletlerin kırık ve deformasyon oluşmadan 9 olguya kadar kullanılabildiği gözlemlenmiştir. Anahtar kelimeler: NiTi döner alet; ProTaper Universal; dental aletler; deformasyon; kırık

\section{References}

1. Pruett JP, Clement DJ, Carnes DL, Jr. Cyclic fatigue testing of nickel-titanium endodontic instruments. J Endod 1997; 23: 7785. [CrossRef]

2. Shen Y, Peng B, Cheung GS. Factors associated with the removal of fractured niti instruments from root canal systems. Oral Surg Oral Med Oral Pathol Oral Radiol Endod 2004; 98: 605-10. [CrossRef]

3. Sattapan B, Nervo GJ, Palamara JE, Messer HH. Defects in rotary nickel-titanium files after clinical use. J Endod 2000; 26: 161-5. [CrossRef]

4. Shen Y, Cheung GS, Bian Z, Peng B. Comparison of defects in profile and protaper systems after clinical use. J Endod 2006; 32: 61-5. [CrossRef]

5. Shen Y, Haapasalo M, Cheung GS, Peng B. Defects in nickel-titanium instruments after clinical use. Part 1: Relationship between observed imperfections and factors leading to such defects in a cohort study. J Endod 2009; 35: 129-32. [CrossRef]

6. Vieira EP, Franca EC, Martins RC, Buono VT, Bahia MG. Influence of multiple clinical use on fatigue resistance of protaper rotary nickel-titanium instruments. Int Endod J 2008; 41: 163-72.
7. Gambarini G. Cyclic fatigue of profile rotary instruments after prolonged clinical use. Int Endod J 2001; 34: 386-9. [CrossRef]

8. Peters OA, Barbakow F. Dynamic torque and apical forces of profile.04 rotary instruments during preparation of curved canals. Int Endod J 2002; 35: 379-89. [CrossRef]

9. Wolcott S, Wolcott J, Ishley D, Kennedy W, Johnson S, Minnich S, Meyers J. Separation incidence of protaper rotary instruments: A large cohort clinical evaluation. J Endod 2006; 32: 1139-41. [CrossRef]

10. Yared GM, Bou Dagher FE, Machtou P. Cyclic fatigue of profile rotary instruments after clinical use. Int Endod J 2000; 33: 204-7. [CrossRef]

11. Yared GM, Dagher FE, Machtou P, Kulkarni GK. Influence of rotational speed, torque and operator proficiency on failure of greater taper files. Int Endod J 2002; 35: 7-12. [CrossRef]

12. Hargreaves KM, Berman LH. Pathways of the pulp. 11 th ed. Missouri, USA: Elsevier 2016, p.209-279.

13. Martin B, Zelada G, Varela P, Bahillo JG, Magan F, Ahn S, Rodriguez $C$. Factors influencing the fracture of nickel-titanium rotary instruments. Int Endod J 2003; 36: 262-6. [CrossRef]

14. Zelada G, Varela P, Martin B, Bahillo JG, Magan F, Ahn S. The effect of rotational speed and the curvature of root canals on the breakage of rotary endodontic instruments. J Endod 2002; 28: 540-2. [CrossRef]

15. Parashos P, Gordon I, Messer HH. Factors influencing defects of rotary nickel-titanium endodontic instruments after clinical use. J Endod 2004; 30: 722-5. [CrossRef]

16. Ullmann CJ, Peters OA. Effect of cyclic fatigue on static fracture loads in protaper nickel-titanium rotary instruments. J Endod 2005; 31: 183-6. [CrossRef]

17. Wu J, Lei G, Yan M, Yu Y, Yu J, Zhang G. Instrument separation analysis of multi-used protaper universal rotary system during root canal therapy. J Endod 2011; 37: 758-63. [CrossRef]

18. Wei X, Ling J, Jiang J, Huang X, Liu L. Modes of failure of protaper nickel-titanium rotary instruments after clinical use. J Endod 2007; 33: 276-9. [CrossRef]

19. Shen Y, Coil JM, McLean AG, Hemerling DL, Haapasalo M. Defects in nickel-titanium instruments after clinical use. Part 5: Single use from endodontic specialty practices. J Endod 2009; 35: 1363-7. [CrossRef]

20. Gambarini G. Rationale for the use of low-torque endodontic motors in root canal instrumentation. Endod Dent Traumatol 2000; 16: 95-100. [CrossRef]

21. Yared GM, Bou Dagher FE, Machtou P. Failure of profile instruments used with high and low torque motors. Int Endod J 2001; 34: 471-5. [CrossRef]

22. Bortnick KL, Steiman HR, Ruskin A. Comparison of nickel-titanium file distortion using electric and air-driven handpieces. J Endod 2001; 27: 57-9. [CrossRef]

23. Valois CR, Silva LP, Azevedo RB. Multiple autoclave cycles affect the surface of rotary nickel-titanium files: An atomic force microscopy study. J Endod 2008; 34: 859-62. [CrossRef]

24. Hilt BR, Cunningham CJ, Shen C, Richards N. Torsional properties of stainless-steel and nickel-titanium files after multiple autoclave sterilizations. J Endod 2000; 26: 76-80. [CrossRef]

25. Regan JD, Sherriff M, Meredith N, Gulabivala K. A survey of interfacial forces used during filing of root canals. Endod Dent Traumatol 2000; 16: 101-6. [CrossRef]

26. Sonntag D, Delschen S, Stachniss V. Root-canal shaping with manual and rotary ni-ti files performed by students. Int Endod J 2003; 36: 715-23. [CrossRef]

27. Yared GM, Bou Dagher FE, Machtou P. Cyclic fatigue of profile rotary instruments after simulated clinical use. Int Endod J 1999; 32: 115-9. [CrossRef] 